\title{
The Dilemma of Teachers in Teaching Controversial Issues of Indonesian History
}

\author{
M. Fakhruddin*, Moch. Soekardjo and Umasih \\ Jakarta State University, Jakarta, Indonesia. \\ "Corresponding author.E-mail: m.fakhruddin_7127140045@mhs.unj.ac.id
}

\begin{abstract}
Controversial history learning in the subject of Indonesian History has so far had many problems, both in terms of teacher readiness, learning resources, learning strategies, and assessment. The purpose of this study is to explore the problems of controversial history learning in Indonesian history subjects, especially regarding the dilemma of teachers in teaching controversial issues. This research is a preliminary study of the controversial history learning program evaluation research through a survey of 30 teachers. The results of the study indicated that there were several research findings as follows. First: there is teacher reluctance in teaching controversial material, and there is even a tendency for teachers to avoid discussing controversial material. Second: teachers feel that they lack knowledge about controversial material and how to teach controversial material. Third: the factors cited as reasons by the teachers were the insufficient supplies they received while studying at the college and the lack of availability of learning resources (textbooks, non-text, or supplements) that support learning controversial historical material. The research implication is the need for colleges to pay special attention to controversial history courses and the History teacher association's need to conduct training on controversial historical learning strategies.
\end{abstract}

Keywords: Controversial Issues, History, Indonesia

\section{INTRODUCTION}

Controversial history is understood as a narrative of a historical event which has various explanations / versions. This is because the various explanations of a historical event are at the root of the controversy [1]. The study of history is very close to a controversial issue [2],[3]. Knowledge of historical events or stories is very limited, either limited supporting facts or limited witnesses who can be used as the first source. All this creates difficulties in establishing a complete historical story. Coupled with the various interpretations of historical events that can be seen from the results of historical stories with different viewpoints. This is why history is so close to controversy. The emergence of controversial history is a necessity in terms of history as a story (histoire recite) [4]. This is because history is an interpretive study of an event. Thus, the latest interpretations are very open to be made. Controversial history arises due to differences in opinions, theories or approaches taken by historians in writing history. This difference is due to the inaccuracy and incompleteness of the facts and interpretations carried out, and usually the inaccuracy arises after several historians have expressed the inaccuracy according to the historian's version [5].

Controversial history learning is an attempt to discuss in the class controversial issues in history on reff [6],[7] This is done by presenting various perspectives about the past in a balanced manner in the classroom. From the perspective of learning history, controversial issues or what is known as controversial history still show two paradoxes. On the one hand, controversial history learning has the potential to develop students' abilities, especially an attitude of thinking that is open to historical debates [8]-[10]. But on the other hand, almost all studies explain that the acceptance of controversial issues in historical learning still faces many obstacles, even rejection in learning praxis [11],[12].

The results of research by The Historical Association, a professional organization of history in the UK on the teaching of sensitive and controversial issues, have the premise that teachers often avoid controversial issues in 
historical learning [13]. Curriculum development opportunities for learning controversial issues in Latvia also explained that there is a tendency for teachers to be afraid to teach controversial issues [14].

\section{METHODOLOGY}

The purpose of this study is to explore the problems of controversial history learning in Indonesian history subjects, especially regarding the dilemma of teachers in teaching controversial issues.

This study uses a quantitative descriptive method through a survey of 30 history teacher respondents in East Jakarta were taken by purposive sampling with the criteria of the management of the high school history MGMP organization. This study is intended as a preliminary study of the controversial history learning program evaluation research that researchers are currently conducting.

\section{RESULTS AND DISCUSSION}

\subsection{Factors Causing Controversial Material}

According to history teachers, there are at least 5 (five) factors that cause controversial historical material as shown in the following diagram:

Based on these data, there are at least 5 (five) factors that cause controversial material on the subject of Indonesian
History, namely, First: Facts and incomplete interpretations; Second: Facts and new interpretations of historical events; Third: The interest of a regime / group to rewrite history; Fourth: Facts \& interpretations that differ from one another and there are interests of certain groups so that many historical facts are distorted according to their interests; Fifth: there are new facts and interpretations, also the interests of the regime.

\subsection{Government Policy on Controversial Historical Material}

Regarding government policies, only 27 percent of respondents stated that there has been a special government policy on controversial historical material, while 73 percent stated that so far there is no specific policy.

For respondents who think there has been a special policy from the government, they argue that the government has published a controversial historical material supplement in 2000. Another reason is that there have been seminars and discussions that have been held to make efforts to straighten history. However, respondents are equally in agreement about the need for the government, in this case the ministry of education, to publish books and or supplements of controversial material as guidelines for history teachers in teaching controversial historical material.

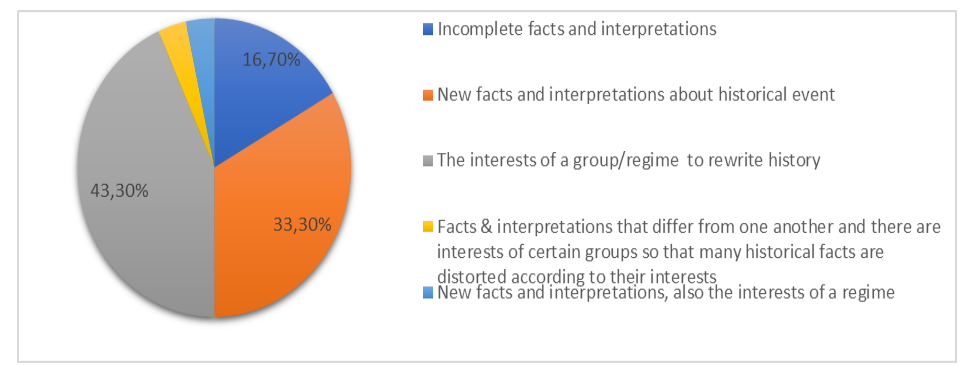

Figure 1. Factors causing controversial historical material

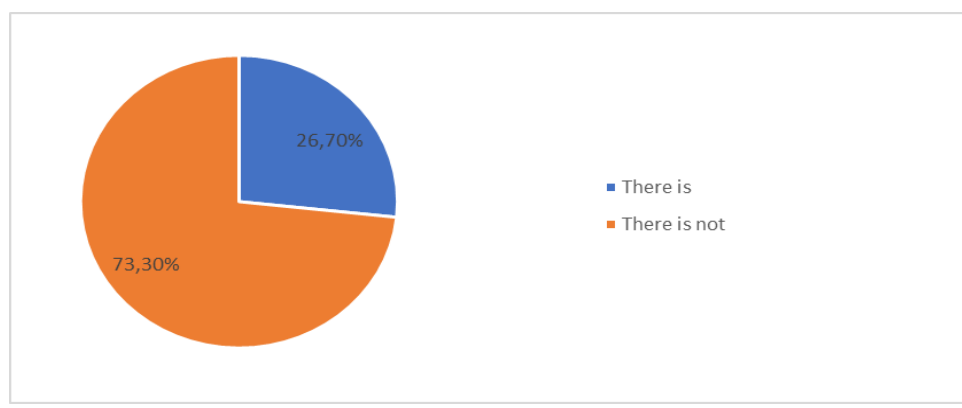

Figure 2. Government Policy on Controversial Historica Material 


\subsection{Resources for Teacher Knowledge on Controversial Historical Materials}

Where is the source of teacher knowledge about controversial historical material? The survey data as presented in the diagram below shows that the largest source was material when they studied in college, then from reading books, seminar materials, professional organizations / MGMP, and other sources such as the internet.

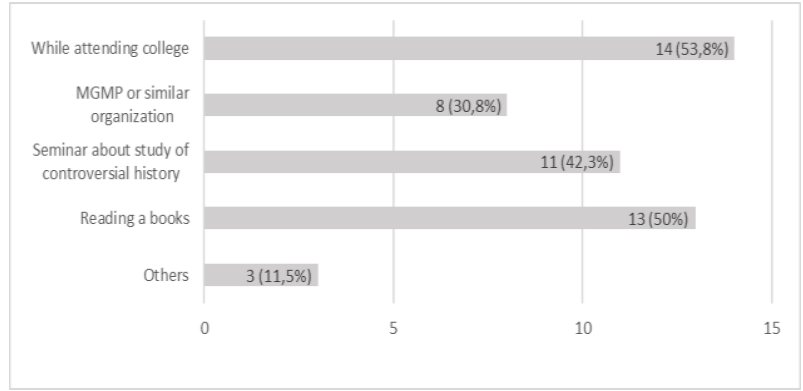

Figure 3. Learning Resources for Controversial Historical Material

It seems that the controversial historical material has not been of particular concern to universities / LPTKs. Teachers who were respondents in this study stated that there were no specific controversial history courses at the colleges where they studied. According to them, their discussion of controversial material is integrated into other courses.

\subsection{Teacher Attention to Controversial Historical Material}

The results showed that in general teachers did not pay special attention to controversial historical material. Some of the reasons they put forward, among others, that they felt they did not have the obligation to teach controversial content because it was not found in Basic Competencies (KD), as well as the Indonesian History syllabus. Materials The materials needed to explain are also not available in Indonesian History teaching materials. In addition, there are also those who mention the reasons for the teacher not having enough time to discuss, the teacher's ignorance and inability to teach controversial historical material, the teacher wants to find it safe because discussing controversial material is a complicated and sensitive discussion, and the teacher has concerns that students will experience confusion to understand the most correct version.

The diagram illustrates several reasons why history teachers' pay less attention to controversial historical material, namely First: students' concern about being confused by the diversity of versions of a historical event $(46 \%)$; Second: lack of teachers' knowledge of controversial historical material (29\%); Third: discussion of controversial material will cause uncertainty about historical material (13\%), Fourth: the reluctance of teachers to discuss controversial material (4\%), Fifth: reluctance of teachers to learn from other sources (4\%), and sixth: fear of the government and the police (4\%).

\section{CONCLUSION}

The results of the study indicated that there were several research findings as follows. First: there is teacher reluctance in teaching controversial material and there is even a tendency for teachers to avoid discussing controversial material. Second: teacher feel that they lack knowledge about controversial material and how to teach controversial material. Third: The factors cited as reasons by the teachers were the insufficient supplies they received while studying at the college and the lack of availability of learning resources (textbooks, non-text, or supplements) that support learning controversial historical material. The research implication is the need for colleges to pay special attention to controversial history courses and the history teacher association's need to conduct training on controversial learning strategies.

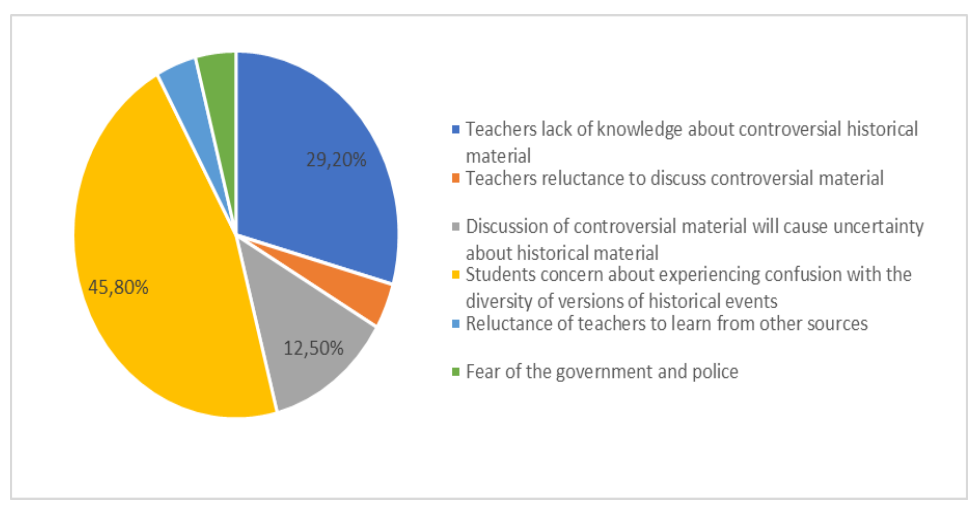

Figure 4. Factors causing history teachers less attention to controversial historical material 


\section{REFERENCES}

[1] D. Reike, W. J. Vermeulen, S. Witjes. The circular economy: new or refurbished as CE 3.0?-exploring controversies in the conceptualization of the circular economy through a focus on history and resource value retention options. Resources, Conservation and Recycl ing, 135 (2018) 246-264. DOI : https://doi.org/10.1016/ j.resconrec.2017.08.027

[2] W. Journell. Framing controversial identity issues in schools: The case of HB2, bathroom equity, and transgender students. Equity \& Excellence in Education, 50 (4) (2017) 339-354. DOI : https://doi.org/ $10.1080 / 10665684.2017 .1393640$

[3] S. A. Metzger, L. M. Harris (Eds.). The Wiley international handbook of history teaching and learning. New York: Wiley-Blackwell.2018.

[4] V. Andréassian. Waters and forests: from historical controversy to scientific debate. Journal of hydrology ,291 (1-2) (2004) 1-27. DOI : https://doi.org/10.1016/j. jhydrol.2003.12.015

[5] N. B. Weidmann. On the accuracy of media-based conflict event data. Journal of Conflict Resolution, 59 (6) (2015) 1129-1149. DOI : https://doi.org/10.1177/00 22002714530431

[6] J. T. King. Teaching and learning about controversial issues: Lessons from Northern Ireland. Theory \& Research in Social Education, 37 (2) (2009) 215-246. DOI : https://doi.org/10.1080/00933104.2009. 10473395

[7] E. Y. Washington, E. K. Humphries. A social studies teacher's sense making of controversial issues discussions of race in a predominantly white, rural high school classroom. Theory \& Research in Social Educati on, 39 (1) (2011) 92-114. DOI : https://doi.org/10.1080 /00933104.2011.10473448

[8] G. Rogers. History, learning technology and student achievement: Making the difference?. Active Learning in Higher Education, 5 (3) (2008) 232-247. DOI : https: //doi.org/10.1177/1469787404043811

[9] G. Ten Dam, M. Volman. Critical thinking as a citizenship competence: teaching strategies. Learning and instruction, 14 (4) (2004) 359-379. DOI: https://doi. org/10.1016/j.learninstruc.2004.01.005
[10] M. C. Woolley. The attitudes and perceptions of beginning teachers in relation to teaching controversial and sensitive issues in the history classroom. Revista Electrónica Interuniversitaria de Formación del Profesorado, 20 (2) (2017) 1-16. DOI : https://doi.org/1 $0.6018 /$ reifop/20.2.284561

[11] T. Goldberg, G. M. Savenije. Teaching controversial historical issues. The Wiley International Handbook of history teaching and learning, (2018) 503526. DOI : 10.1002/9781119100812

[12] G. M. Savenije, N. Brauch, W. Wagner. Sensitivities in history teaching across Europe and Israel. Pedagogy, Culture \& Society, 27 (1) (2019) 1-6. DOI : https://doi.org/10.1080/14681366.2019.1566163

[13] J. Wassermann, D. Bentrovato. Confronting controversial issues in History classrooms: an analysis of pre-service high school teachers' experiences in postapartheid South Africa. Yesterday and Today, (20) (2018) 72-90. DOI : http://dx.doi.org/10.17159/22230386/2018/n19a4

[14] J. Madalińska-Michalak, B. Bavli. Challenges in teaching English as a foreign language at schools in Poland and Turkey. European Journal of Teacher Education, 41 (5) (2018) 688-706. DOI : https://doi.org/ $10.1080 / 02619768.2018 .1531125$ 